\title{
Granulometric and oxidizable carbon fractions of soil organic matter in crop-livestock integration systems
}

\section{Frações oxidáveis e granulométricas da matéria orgânica em sistemas de integração lavoura-pecuária}

\author{
Wanderlei Bieluczyk ${ }^{1 *}$; Marcos Gervasio Pereira²; \\ Roni Fernandes Guareschi ; João de Andrade Bonetti'; \\ Vanessa Aparecida Freós; Eduardo Carvalho da Silva Neto ${ }^{6}$
}

\begin{abstract}
The identification of the labile and recalcitrant forms of soil organic matter (SOM) allows to rapidly define, or even predict if the management used favors increments or losses of carbon in the soil. Thus, the objective of this work was to assess the effects of different grazing intensities and soybean crops on the oxidizable and granulometric fractions of the SOM in a crop-livestock integration combined with no-tillage system (CLI-NTS), established in 2009 in the Goiás Federal University. The treatments consisted of three different pasture heights $(0.25 \mathrm{~m} \mathrm{P} 25 ; 0.35 \mathrm{~m} \mathrm{P} 35 ; 0.45 \mathrm{~m} \mathrm{P} 45)$, and areas without grazing (AWG), and a native vegetation area of the Cerrado biome (NCA), adjacent to the experimental area, was evaluated as references and compared with the cultivated areas. Soil samples (Oxisol - USDA; typic distroferric Red Latosol - SiBCS) were collected in the layers 0.00-0.05; 0.05-0.10 0.10-0.20 and $0.20-0.40 \mathrm{~m}$ of each area, and arranged in a completely randomized experimental design with six replications. The soil total carbon was quantified (TC) by dry combustion. The SOM granulometry and oxidizable SOM were fractionated into particulate carbon (OCp), carbon bond with minerals $(\mathrm{OCm})$ and four oxidizable fractions with increasing degrees of recalcitrance $(\mathrm{F} 1<\mathrm{F} 2<\mathrm{F} 3<\mathrm{F} 4)$. These soil attributes were evaluated at two different times, representing the post-pasture cycle (PP) and post-soybean crop (PC) periods. The lower contents of total soil carbon (TC) were found in the F1 and F3 fractions of the area without grazing, suggesting that the crop-livestock integration increases the organic matter content in the soil surface layer regardless of the pasture height. The areas without grazing and with different pasture heights in CLI had similar contents of OCp and OCm due to the experiment short time of implementation (3 years). The fractionation of the oxidizable SOM was more sensitive in differentiating the treatments, showing that the higher intensity of grazing used (P25) provided a better balance of carbon accumulation between the SOM labile and recalcitrant fractions.
\end{abstract}

Key words: Urochloa ruziziensis. Grazing intensities. SOM fractionation. Cerrado.

${ }^{1}$ Discente do Curso de Doutorado do Programa de Pós-Graduação em Ciências, Energia Nuclear na Agricultura, Laboratório de Ciclagem de Nutrientes, Centro de Energia Nuclear na Agricultura, Universidade de São Paulo, CENA/USP, Piracicaba, SP, Brasil. E-mail: wanderleibieluczyk@gmail.com

2 Prof. Dr., Departamento de Solos, Universidade Federal Rural do Rio de Janeiro, UFRRJ, Seropédica, RJ, Brasil. E-mail: mgervasiopereira@gmail.com

${ }^{3}$ Dr., Pós-Doutorando em Fitotecnia, Curso de Pós-Graduação em Fitotecnia, UFRRJ, Seropédica, RJ, Brasil. E-mail: guareschiecotarelli@hotmail.com

4 Discente do Curso de Doutorado do Programa de Pós-Graduação em Agronomia, Ciência do Solo, Universidade Federal do Rio Grande do Sul, UFRGS, Porto Alegre, RS, Brasil. E-mail: agro.bonetti@gmail.com

5 Discente do Curso de Engenharia Agronômica, UFRRJ, Seropédica, RJ, Brasil. E-mail: wanessafreo@gmail.com

${ }^{6}$ Discente de Mestrado do Curso de Pós-Graduação em Agronomia, Ciência do Solo, UFRRJ, Seropédica, RJ, Brasil. E-mail: netocseduardo@gmail.com

* Author for correspondence 


\section{Resumo}

Por meio da identificação de formas lábeis e recalcitrantes da matéria orgânica do solo (SOM) se torna possível definir de forma mais imediata, ou até prever se o manejo favorece e/ou favorecerá incrementos ou perdas de carbono no solo. Diante disso, o objetivo deste estudo foi avaliar os efeitos de diferentes intensidades de pastejo e cultivo da soja nas frações oxidáveis e granulométricas da SOM em um sistema de integração lavoura-pecuária associado ao plantio direto (ILP-SPD), implantado em 2009, na Universidade Federal Goiás, GO. Os cinco tratamentos estudados consistiram de diferentes alturas de manejo do pasto (P25: 0,25 m; P35: 0,35 m; e P45: 0,45 m), além de áreas controle sem pastejo (SP) e uma área de vegetação nativa de cerrado (cerradão) (CE) adjacente ao experimento utilizada como referência para comparação com as áreas cultivadas. Em cada área, amostras de um LATOSSOLO VERMELHO Distroférrico foram coletadas nas camadas de $0,0-0,05 ; 0,05-0,10 ; 0,10-0,20 ; 0,20-0,40 \mathrm{~m}$ em delineamento inteiramente casualizado com 6 repetições. Foi quantificado o carbono total (CT) por combustão a seco. Também foi realizado o fracionamento granulométrico e oxidável da MOS, obtendose as frações, carbono particulado (COp), carbono associado aos minerais (COam) e as quatro frações oxidáveis com graus crescentes de recalcitrância $(\mathrm{F} 1<\mathrm{F} 2<\mathrm{F} 3<\mathrm{F} 4)$. Tais atributos foram avaliados em duas épocas distintas: uma pós-ciclo de pastejo (PP) e outra pós-lavoura de soja (PL). Os menores teores de carbono total do solo $(\mathrm{C})$, fração $\mathrm{F} 1$ e fração $\mathrm{F} 3$ da área não pastejada, sugerem que a integração lavoura pecuária, independentemente da altura de manejo da pastagem, está incrementando o teor de matéria orgânica na camada superficial do solo. Devido à recente implantação do experimento (3 anos), não foi constatado diferenças nos teores de COp e COam entre as áreas sem pastagem e as diferentes alturas de manejo de pasto na ILP. O fracionamento oxidável da MOS mostrou-se mais sensível na diferenciação dos tratamentos estudados, evidenciando que a maior intensidade de pastejo (P25) está proporcionando um maior equilíbrio no acúmulo de carbono entre frações lábeis e recalcitrantes da MOS.

Palavras-chave: Urochloa ruziziensis. Intensidades de pastejo. Fracionamento da MOS. Cerrado.

\section{Introduction}

The crop-livestock integration (CLI) combined with the no-tillage system (NTS) is an excellent alternative to ensure the livestock expansion without requiring new areas, using a low-carbon strategy (MARTHA JUNIOR et al., 2011) and recovering degraded areas by modern agriculture (LOSS et al., 2012). Inadequate techniques and land uses have caused rapid degradation of areas in the Cerrado biome, with organic matter and nutrient losses (RESCK et al., 2008).

The reduction of the soil organic matter (SOM) content is very harmful to the Oxisols of the Cerrado biome, since this fraction is responsible for $75-85 \%$ of the cation exchange capacity (CEC) in these soils (CIOTTA et al., 2003; OORTS et al., 2003).

CLI is a recent system with many variations throughout Brazil, thus, further studies must be conducted to identify the influence of this system on the SOM dynamic (GAZOLLA et al., 2015).
Studies on the SOM fractions and their relations with managements aim to develop strategies for increasing their contents in cultivated soils and a better understanding of their dynamics (BATISTA et al., 2013). The SOM fractions have different chemical, physical and morphological characteristics, and their distribution in the soil can indicate the organic matter quality (CARMO et al., 2012). Thus, management systems such as the CLI change the SOM labile:non-labile ratio by providing different amounts of organic materials and carbon to the soil (CARMO et al., 2012), allowing to use the granulometric and oxidizable SOM fractions as indicators of changes caused by different managements and land uses (FIGUEIREDO et al., 2010; SALTON et al., 2011; CARMO et al., 2012; BATISTA et al., 2013; GAZOLLA et al., 2015).

The fractionation of the granulometric SOM determines the organic carbon of sand size (diameter $\geq 53 \mu \mathrm{m}$ ), known as particulate organic 
carbon (OCp), and of silt and clay sizes (diameter $<53 \mu \mathrm{m})$, known as organic carbon bond to minerals (OCm) (BATISTA et al, 2013). OCp is more labile and exhibits high sensitivity to changes caused by managements (CARMO et al., 2012; BATISTA et al., 2013; GAZOLLA et al., 2015), while the OCm is more recalcitrant and have slow cycling (BAYER et al., 2004), thus, this fraction is more stable and less sensitivity to soil changes (SALTON, 2005).

Different results are found in the literature regarding the fractionation of the granulometric SOM performed in Oxisols under CLI in the Cerrado (CARMO et al., 2012; ROSSI et al., 2012; TIRLONI et al., 2012; GAZOLLA et al., 2015). Gazolla et al. (2015), evaluated an Oxisol area under CLI in the Cerrado biome and found lower OCp contents in the surface layer compared with a native area, however, they found similar OCp contents in the layer $0,10-0,40 \mathrm{~m}$ of these areas. These authors found greater OCm contents in the surface layer and lower in the subsurface layer compared with the native vegetation. Rossi et al. (2012) compared CLI and native areas (Cerrado) in the same region of the present study and found greater OCp and smaller OCm contents in the soil layer $0,0-0,20 \mathrm{~m}$ of the CLI area. Tirloni et al. (2012) found similar values of OCp and OCm in CLI and native forest areas. Carmo et al. (2012) evaluated an Oxisol area under CLI in the Cerrado biome and found greater OCp and OCm contents in the CLI compared with the native vegetation area.

These divergent results of OCp and OCm contents found in CLI in the Cerrado biome are due to four main factors, the variations in edaphoclimatic characteristics, different times of CLI implementation, different crop species and rotations used, and contents of plant residue intrinsic to each system, depending on the crops and the different grazing cycles and intensity. The grazing intensity is very important, since this management controls the amount of plant residues that will be left by the off-season crop to ensure sufficient straw contents for the following crop to be carried out in the summer season using the no-tillage system (NTS) (BIELUCZYK, 2014; BONETTI et al., 2015).

The fractionation of the oxidizable SOM proposed by Chan et al. (2001), differentiates four fractions with decreasing degrees of oxidation of the SOM, using increasing concentrations of sulfuric acid. The F1 and F2 fractions are related to nutrient availability and macroaggregate formation (CHAN et al., 2001; BLAIR et al, 1995). The F1 fraction has the greatest lability in the soil and is highly correlated with the light SOM fraction (MAIA et al., 2007). The F3 and F4 fractions are related to compounds from the SOM decomposition and humification that are more chemically stable and have greater molecular weight (STEVENSON, 1994). The F4 fraction, also called passive fraction in SOM simulation models, is the most resistant in the soil, with recycle time of up to 2,000 years (CHAN et al., 2001). The $\mathrm{C}$ balance in the oxidizable fractions is important in integrated production systems, i.e., $50 \%$ of $\mathrm{F} 1+\mathrm{F} 2$ and $50 \%$ of $\mathrm{F} 3+\mathrm{F} 4$ fractions, thus, part of the organic matter is easily decomposable for nutrients mineralization and part is more resistant in the soil, improving and maintaining the soil physical properties (LOSS et al., 2009).

Few studies in the literature have evaluated the dynamics of the oxidizable SOM fractions in Oxisol under CLI in the Cerrado biome (LOSS et al., 2013; BATISTA et al., 2014). Batista et al. (2014) found similar F1 and F2 fractions in CLI and Cerrado areas, and smaller amounts of F3 and F4 fractions in the CLI $(0.10-0,30 \mathrm{~m})$ compared with the native vegetation. Similarly, Loss et al. (2013) found smaller amounts of F3 and F4 fractions in CLI compared with native vegetation (Cerrado), however, the F1 and F2 fractions in CLI presented greater amounts in some layers. According to these authors, the organic residues in the CLI from the cattle manure, litterfall and plant roots are correlated with increases in the oxidizable fractions F1 and F2.

Therefore, the combined inputs of organic residues from crops, grasses and cattle, can change 
the SOM dynamics; and the grazing intensity on the forage grass in the crop off season is directly related to the $\mathrm{C}$ input to the system. Thus, the objective of this work was to assess the effects of different grazing intensities and soybean crops on the oxidizable and granulometric fractions of the SOM in crop-livestock integration combined with no-tillage system (CLIS-NTS).

\section{Material and Methods}

The experiment was conducted in the experimental area of the Goias Federal University
(UFG), Jatai campus $\left(17^{\circ} 56{ }^{\prime} 57^{\prime} \mathrm{S}, 51^{\circ} 43^{\prime} 18^{\prime \prime} \mathrm{W}\right.$ and altitude of $800 \mathrm{~m}$ ). The soil of the region was classified as Oxisol (typic distroferric Red Latosol - SiBCS) with slightly rugged terrain (EMBRAPA, 2013; BONETTI et al., 2015).

The region climate is tropical rainy (Aw), according to the Köppen classification, and has two defined seasons, a rainy (October to April) and a dry season (May to September). The region has annual average temperature of $22^{\circ} \mathrm{C}$ and annual average precipitation of $1600 \mathrm{~mm}$. The monthly average temperature and precipitation of the 2012/2013 season crop are shown in Figure 1.

Figure 1. Precipitation and average monthly temperatures in the 2012/2013 crop season.

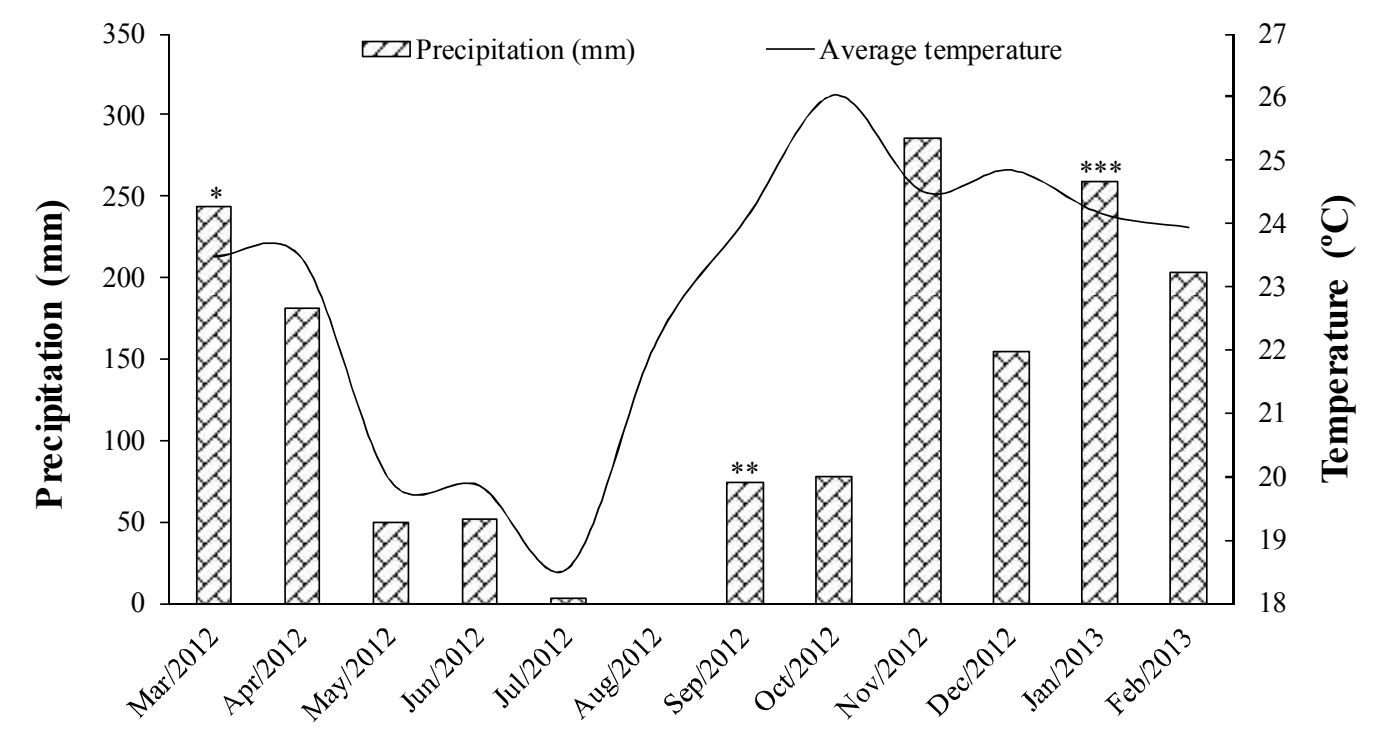

*Urochloa ruziziensis sowing; **Soybean sowing; ***Soybean harvest.

Source: INMET Weather Station of Jatai (N. 83464).

The experimental area had high degradation level, low plant production and presence of weeds by the experiment implementation, due to inadequate managements of the grass (Brachiaria decumbens) and grazing throughout about twenty years before the experiment.

Soil liming with dolomitic limestone $\left(2.5 \mathrm{Mg}^{-} \mathrm{ha}^{-}\right.$ ${ }^{1}$, TNP $80 \%$ ) was carried out in May, 2009, raising the base saturation to $60 \%$. The lime was incorporated into the soil by one plowing and two harrowing. Another liming with dolomitic limestone $(2.3 \mathrm{Mg}$ $\mathrm{ha}^{-1}$, TNP $80 \%$ ) was applied to the soil surface in the 2011/2012 crop season, according to the soil chemical analysis, raising the base saturation to $60 \%$ (Figure 2).

The plants in the experimental area were desiccated in October 2009, using glyphosate (4.0 L $\left.\mathrm{ha}^{-1}\right)$. The soybean was sowed with spacing of $0.45 \mathrm{~m}$ 
between rows and density of approximately 340,000 plants $\mathrm{ha}^{-1}$. Fertilization was carried out with $350 \mathrm{~kg}$ ha $^{-1}$ of NPK (2:18:18) (SOUSA; LOBATO, 2004). Pesticide applications (herbicides, insecticides and fungicides) were carried out as needed. Harvesting were performed usually at early February of each year, since the soybean used had an early cycle.

Figure 2. Land use history of the assessed areas, liming and sampling timing.

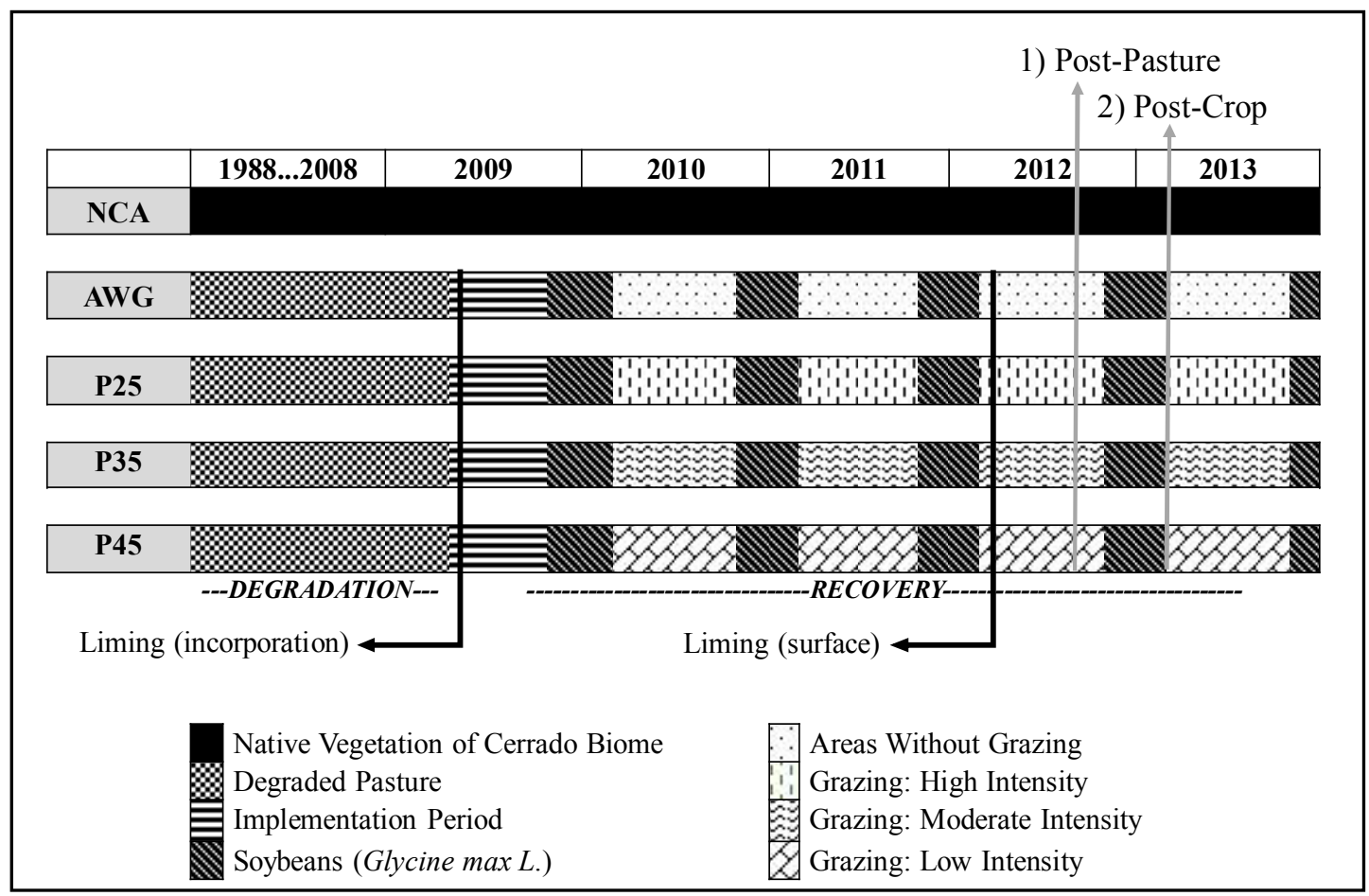

*Areas without grazing (AWG). **Areas with different pasture heights (P25 $0.25 \mathrm{~m}$; P35 $0.35 \mathrm{~m}$, and P45 0.45 m).

Urochloa ruziziensis seeds were subsequently sowed (10 kg ha-1; germination index of $65 \%)$ in rows, using direct seeding. About 45 days after plants emergence, $150 \mathrm{~kg} \mathrm{ha}^{-1}$ of nitrogen (urea) was applied (SOUSA; LOBATO, 2004). Electric fences were installed in the area in June, and the grazing started in July, 95 days after the $U$. ruziziensis emergence.

The grazing started in winter, followed by the summer crop (soybean) (Figure 2). The total area of the experiment was approximately 22 ha, which was divided into experimental plots of about 2.0 ha, arranged in a randomized block design with six replications. The treatments consisted of three different pasture heights, 0.25 (P25), 0.35 (P35) and 0.45 (P45) meters, with areas of same size without grazing (AWG) between the blocks as control. A native vegetation area of the Cerrado biome (NCA), adjacent to the experimental area, was used as an additional control area of reference for comparison with the cultivated areas.

The animals were introduced to the areas when the pasture had average grass accumulation of approximately $4,000 \mathrm{~kg}$ of dry biomass $\mathrm{ha}^{-1}$ and average height of $1.03 \mathrm{~m}$. The grazing started in July, extending to mid-October, totaling 120 days. The grazing system was continuous, starting with animals of average weight of 1 animal unit $(\mathrm{AU}=450$ $\mathrm{kg}$ ) (BONETTI et al., 2015). The animal densities used was 1.5 (P25), 2.5 (P35) and 3.5 (P45) AU ha-1. The pasture heights of the different treatments were monitored every 14 days, using a sward stick in 
50 points of each plot. The desired pasture heights were obtained approximately 20 days after the cattle introductions, which were removed when needed to maintain the pasture heights of each treatment.

Trenches were excavated in each area (P25, P35, P45, AWG and NCA) and six composite soil samples, consisting of three single samples, were collected from the soil layers $0.00-0.05 ; 0.05-0.10$, $0.10-0.20$ and $0.20-0.40 \mathrm{~m}$. The samples were air dried, disaggregated and sieved in a 2-mm mesh sieve, obtaining the air-dried ground soil (ADGS) for the characterization of the soil fertility and granulometry (DONAGEMA et al., 2011) (Table 1).

Table 1. Soil chemical and granulometric analysis of treatments with different pasture heights (P25 $0.25 \mathrm{~m}$; P35 0.35 $\mathrm{m}$, and P45 $0.45 \mathrm{~m}$ ), areas without grazing (AWG) and an native vegetation area of the Cerrado biome (NCA).

\begin{tabular}{|c|c|c|c|c|c|c|c|c|c|c|c|}
\hline \multirow{3}{*}{ *Area } & $\mathrm{pH}$ & $\mathrm{P}$ & $\mathrm{Ca}$ & $\mathrm{Mg}$ & $\mathrm{K}$ & $\mathrm{H}+\mathrm{Al}$ & $\begin{array}{c}\text { CEC } \\
(\mathrm{pH} 7)\end{array}$ & V & Clay & Silt & Sand \\
\hline & $\mathrm{H}_{2} \mathrm{O}$ & $\mathrm{mg} \mathrm{kg}^{-1}$ & \multicolumn{5}{|c|}{-------------- cmol $\mathrm{kg}^{-1}$------------ } & $--\%--$ & \multicolumn{3}{|c|}{---------- $\mathrm{g} \mathrm{kg}^{-1}$---------. } \\
\hline & \multicolumn{11}{|c|}{$0.0-0.05 \mathrm{~m}$} \\
\hline $\mathrm{NCA}$ & 5.16 & 1.06 & 0.90 & 0.86 & 0.19 & 5.21 & 7.17 & 27.08 & 394 & 257 & 349 \\
\hline AWG & 6.17 & 3.60 & 2.89 & 1.86 & 0.33 & 2.99 & 8.09 & 61.94 & 411 & 251 & 338 \\
\hline P25 & 5.95 & 2.91 & 2.37 & 1.45 & 0.28 & 3.84 & 7.95 & 51.59 & 442 & 224 & 334 \\
\hline P35 & 6.09 & 2.88 & 2.69 & 1.73 & 0.47 & 3.68 & 8.58 & 56.79 & 417 & 245 & 338 \\
\hline \multirow[t]{2}{*}{$\mathrm{P} 45$} & 5.85 & 1.06 & 2.08 & 1.21 & 0.23 & 4.26 & 7.78 & 45.24 & 414 & 248 & 338 \\
\hline & \multicolumn{11}{|c|}{$0.05-0.10 \mathrm{~m}$} \\
\hline $\mathrm{NCA}$ & 5.19 & 0.80 & 0.43 & 0.43 & 0.09 & 5.68 & 6.65 & 14.06 & 416 & 226 & 358 \\
\hline AWG & 5.58 & 1.00 & 1.25 & 0.85 & 0.07 & 4.25 & 6.43 & 34.10 & 444 & 221 & 335 \\
\hline $\mathrm{P} 25$ & 5.50 & 1.39 & 1.29 & 1.09 & 0.07 & 4.72 & 7.18 & 33.48 & 448 & 215 & 337 \\
\hline P35 & 5.42 & 1.48 & 1.26 & 0.96 & 0.10 & 4.92 & 7.24 & 31.26 & 442 & 222 & 336 \\
\hline \multirow[t]{2}{*}{$\mathrm{P} 45$} & 5.54 & 1.02 & 1.20 & 0.78 & 0.06 & 4.85 & 6.90 & 29.73 & 443 & 226 & 331 \\
\hline & \multicolumn{11}{|c|}{$0.10-0.20 \mathrm{~m}$} \\
\hline $\mathrm{NCA}$ & 5.47 & 0.51 & 0.31 & 0.36 & 0.07 & 5.43 & 6.19 & 12.07 & 386 & 266 & 349 \\
\hline AWG & 5.37 & 0.56 & 0.80 & 0.55 & 0.05 & 4.33 & 5.74 & 24.26 & 400 & 251 & 349 \\
\hline P25 & 5.33 & 0.60 & 0.81 & 0.54 & 0.04 & 4.20 & 5.60 & 24.15 & 444 & 233 & 323 \\
\hline P35 & 5.43 & 0.60 & 0.71 & 0.53 & 0.05 & 4.23 & 5.51 & 22.97 & 447 & 219 & 335 \\
\hline \multirow[t]{2}{*}{$\mathrm{P} 45$} & 5.48 & 0.62 & 0.73 & 0.65 & 0.04 & 4.21 & 5.64 & 25.26 & 429 & 229 & 343 \\
\hline & \multicolumn{11}{|c|}{$0.20-0.40 \mathrm{~m}$} \\
\hline $\mathrm{NCA}$ & 5.45 & 0.38 & 0.30 & 0.29 & 0.07 & 4.99 & 5.66 & 11.54 & 420 & 237 & 344 \\
\hline AWG & 5.55 & 0.54 & 0.48 & 0.35 & 0.03 & 3.32 & 4.18 & 18.99 & 406 & 229 & 365 \\
\hline P25 & 5.55 & 0.46 & 0.45 & 0.22 & 0.03 & 2.99 & 3.69 & 18.44 & 470 & 205 & 325 \\
\hline P35 & 5.52 & 0.50 & 0.40 & 0.30 & 0.03 & 3.32 & 4.05 & 17.57 & 445 & 218 & 338 \\
\hline P45 & 5.50 & 0.50 & 0.37 & 0.40 & 0.03 & 3.16 & 3.95 & 19.99 & 448 & 217 & 334 \\
\hline
\end{tabular}

* In these areas the values of the variables are related to soil sampling after grazing period.

Two soil samplings were carried out, one at postpasture (PP) after the cattle grazing (October 2012) and other at post-crop (PC), when the soybean was at physiological maturity (February 2013), in order to identify the impacts of the livestock and agriculture managements on the attributes evaluated (Figure 2). The samplings in the Cerrado area (NCA) were carried out at the same time of the samplings in the areas under cultivation, in the dry (October 2012) and rainy (February 2013) seasons (Figure 1). The Cerrado area evaluated had 100x100 m and the soil sampling was carried out in random points.

The total soil carbon content (TC) was quantified by dry combustion in an $\mathrm{CHN}$ analyzer (CHN-600 Carlo Erba EA 1110, Italy). 
The soil organic matter (SOM) was subjected to granulometric physical fractionation (CAMBARDELLA; ELLIOT, 1992). Thus, $30 \mathrm{~mL}$ of a sodium hexametaphosphate $\left(5 \mathrm{~g} \mathrm{~L}^{-1}\right)$ solution was added to $10 \mathrm{~g}$ of soil, shaken for 15 hours in a horizontal shaker, and the suspension was washed in a 53- $\mu \mathrm{m}$ mesh sieve with a water jet. The material retained on the sieve was dried in an oven at $50^{\circ} \mathrm{C}$ and weighed (sand fraction). The carbon of the sand was quantified through the dry combustion method.

Subsequently, the $\mathrm{C}$ content of the sand were used to calculate the content of the soil particulatecarbon (OCp), using the equation $\mathrm{OCp}=\mathrm{C}$-sand (Sand/10), where the $\mathrm{C}$-sand is the carbon of the sand fraction $\left(\mathrm{g} \mathrm{kg}^{-1}\right)$ and Sand is the content retained in the $53-\mu \mathrm{m}$ mesh sieve $(\mathrm{g})$.

The material that passed through the $53-\mu \mathrm{m}$ mesh sieve consisted of carbon bond with minerals $(\mathrm{OCm})$ from the silt and clay fractions, whose weight was calculated by the difference between the total $\mathrm{C}$ and $\mathrm{OCp}$.

The carbon was fractionated by oxidation degree (CHAN et al., 2001), thus, $0.3 \mathrm{~g}$ of soil were placed in $250 \mathrm{ml}$ Erlenmeyer flask and $10 \mathrm{ml}$ of $\mathrm{K}_{2} \mathrm{Cr}_{2} \mathrm{O}_{7}$ $\left(0.167 \mathrm{~mol} \mathrm{~L}^{-1}\right)$ and $\mathrm{H}_{2} \mathrm{SO}_{4}$ at concentrations of 3 , 6, 9 and $12 \mathrm{~mol} \mathrm{~L}^{-1}$ was added to it. The oxidation was carried out without external supply of heat and the titration of the extracts was performed using a $\mathrm{Fe}\left(\mathrm{NH}_{4}\right)_{2}\left(\mathrm{SO}_{4}\right)_{2} \cdot 6 \mathrm{H}_{2} \mathrm{O}\left(0.5 \mathrm{~mol} \mathrm{~L} \mathrm{~L}^{-1}\right)$ solution. Phenanthroline was used as indicator. Four fractions with decreasing degrees of oxidation were obtained, F1 ( $C$ oxidized by $\mathrm{K}_{2} \mathrm{Cr}_{2} \mathrm{O}_{7}$ in acid medium of 3 mol L-1 of $\mathrm{H}_{2} \mathrm{SO}_{4}$ ), $\mathrm{F} 2$ (difference between the $\mathrm{C}$ oxidized by $\mathrm{K} 2 \mathrm{Cr} 2 \mathrm{O} 7$ in acidic medium of 6 and 3 mol L-1 of $\mathrm{H}_{2} \mathrm{SO}_{4}$ ), $\mathrm{F} 3$ ( $\mathrm{C}$ difference between the $\mathrm{C}$ oxidized by $\mathrm{K} 2 \mathrm{Cr} 2 \mathrm{O} 7$ in acidic medium of 9 and 6 mol L-1 of $\mathrm{H}_{2} \mathrm{SO}_{4}$ ) and $\mathrm{F} 4$ ( $\mathrm{C}$ difference between the $\mathrm{C}$ oxidized by $\mathrm{K} 2 \mathrm{Cr} 2 \mathrm{O} 7$ in acidic medium of 12 and $9 \mathrm{~mol} \mathrm{~L}^{-1}$ of $\mathrm{H}_{2} \mathrm{SO}_{4}$ ).

The soil total organic carbon (TOC), which was used to validate the results of the fractionation of the oxidizable SOM, was determined by the wet combustion method (YEOMANS; BREMNER, 1988).

Statistical analysis was carried out to evaluate the data, using a $5 \times 2$ factorial arrangement with six replications, five different areas (P25, P35, $\mathrm{P} 45, \mathrm{AWG}$ and $\mathrm{NCA}$ ) and two evaluation times (PP and PC). All data of each layer was subjected to data normality test (Lilliefors) and homogeneity of variances (Cochran and Barttlet). Subsequently, the results were subjected to analysis of variance by the $\mathrm{F}$ test and the values were compared by the Tukey's test at $5 \%$ of probability, using the software ASSISTAT.

\section{Results and Discussion}

The native vegetation area of the Cerrado biome (NCA) had greater total carbon (TC) content than the other treatments in the layer $0.0-0.05 \mathrm{~m}$ in the post-pasture (PP) and in the layer $0.10-0.40 \mathrm{~m}$ in the PP and post-crop (PC) periods (Table 2). These greater TC contents in the NCA were related to its greater amount of plant residues on the soil surface due to the vegetation in this area and the absence of human disturbances. Similar results were reported by Batista et al. (2013), Tirloni et al. (2012) and Gazolla et al. (2015), who found greater TOC contents in areas of native vegetation compared with CLI areas. 
Table 2. Total Carbon $(\mathrm{C})$, carbon bond with minerals $(\mathrm{OCm})$ and particulate carbon $(\mathrm{OCp})$ in an area with native vegetation (Cerrado biome) and areas with crop-livestock integration with different grazing intensities in no-tillage system.

\begin{tabular}{|c|c|c|c|c|c|c|}
\hline \multirow{4}{*}{ Areas $^{* *}$} & \multicolumn{2}{|c|}{$\mathbf{C}$} & \multicolumn{2}{|c|}{$\mathbf{O C m}$} & \multicolumn{2}{|c|}{ OCp } \\
\hline & \multicolumn{6}{|c|}{ 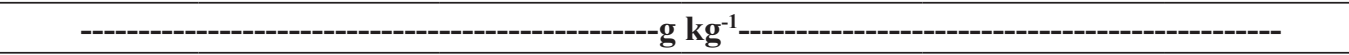 } \\
\hline & \multicolumn{6}{|c|}{$0.0-0.05 \mathrm{~m}$} \\
\hline & $\mathbf{P P}$ & $\mathbf{P C}$ & $\mathbf{P P}$ & PC & PP & PC \\
\hline NCA & $40.67 \mathrm{Aa}^{*}$ & $41.27 \mathrm{Aa}$ & $34.49 \mathrm{Aa}$ & $36.63 \mathrm{Aa}$ & $6.18 \mathrm{Aa}$ & $4.63 \mathrm{Ab}$ \\
\hline AWG & $28.10 \mathrm{Ba}$ & $21.38 \mathrm{Bb}$ & $24.07 \mathrm{Aa}$ & $19.05 \mathrm{Ba}$ & $4.03 \mathrm{Ba}$ & $2.32 \mathrm{Ba}$ \\
\hline $\mathbf{P 2 5}$ & $27.32 \mathrm{Ba}$ & $28.80 \mathrm{ABa}$ & $23.70 \mathrm{Aa}$ & $26.25 \mathrm{Ba}$ & $3.62 \mathrm{Ba}$ & $2.55 \mathrm{Ba}$ \\
\hline P35 & $27.45 \mathrm{Ba}$ & $27.60 \mathrm{ABa}$ & $23.79 \mathrm{Aa}$ & $25.17 \mathrm{Ba}$ & $3.66 \mathrm{Ba}$ & $2.43 \mathrm{Ba}$ \\
\hline \multirow[t]{4}{*}{ P45 } & $27.00 \mathrm{Ba}$ & $27.27 \mathrm{ABa}$ & $23.52 \mathrm{Aa}$ & $24.52 \mathrm{Ba}$ & $3.48 \mathrm{Ba}$ & $2.75 \mathrm{Ba}$ \\
\hline & \multicolumn{2}{|c|}{$\mathrm{CV}(1): 25.45$} & \multicolumn{2}{|c|}{ CV(1): 26.88} & \multicolumn{2}{|c|}{$\mathrm{CV}(1): 32.52$} \\
\hline & \multicolumn{2}{|c|}{$\mathrm{CV}(2): 15.03$} & \multicolumn{2}{|c|}{$\mathrm{CV}(2): 15.04$} & \multicolumn{2}{|c|}{$\mathrm{CV}(2): 43.26$} \\
\hline & \multicolumn{6}{|c|}{$0.05-0.10 \mathrm{~m}$} \\
\hline NCA & $33.27 \mathrm{Aa}$ & $30.95 \mathrm{Aa}$ & $29.02 \mathrm{Aa}$ & $27.66 \mathrm{Aa}$ & $4.25 \mathrm{Aa}$ & $3.29 \mathrm{Ab}$ \\
\hline AWG & $25.55 \mathrm{Ba}$ & $23.13 \mathrm{Ba}$ & $23.18 \mathrm{Aa}$ & $21.00 \mathrm{Aa}$ & $2.37 \mathrm{Ba}$ & $2.13 \mathrm{Ba}$ \\
\hline P25 & $26.27 \mathrm{ABa}$ & $30.45 \mathrm{Aa}$ & $23.80 \mathrm{Aa}$ & $28.47 \mathrm{Aa}$ & $2.47 \mathrm{Ba}$ & $1.98 \mathrm{Ba}$ \\
\hline P35 & $25.87 \mathrm{ABa}$ & $26.42 \mathrm{ABa}$ & $23.49 \mathrm{Aa}$ & $24.06 \mathrm{Aa}$ & $2.38 \mathrm{Ba}$ & $2.35 \mathrm{ABa}$ \\
\hline \multirow[t]{4}{*}{ P45 } & $25.28 \mathrm{Ba}$ & $24.83 \mathrm{ABa}$ & $23.36 \mathrm{Aa}$ & $22.85 \mathrm{Aa}$ & $1.92 \mathrm{Ba}$ & $1.98 \mathrm{Ba}$ \\
\hline & \multicolumn{2}{|c|}{ CV (1): 14.84} & \multicolumn{2}{|c|}{ CV(1): 15.83} & \multicolumn{2}{|c|}{ CV(1): 29.29} \\
\hline & \multicolumn{2}{|c|}{ CV (2): 9.03} & \multicolumn{2}{|c|}{$\mathrm{CV}(2): 16.86$} & \multicolumn{2}{|c|}{$\mathrm{CV}(2): 22.48$} \\
\hline & \multicolumn{6}{|c|}{$0.10-0.20 \mathrm{~m}$} \\
\hline NCA & $30.40 \mathrm{Aa}$ & $28.85 \mathrm{Aa}$ & $26.59 \mathrm{Aa}$ & $25.66 \mathrm{Aa}$ & $3.81 \mathrm{Aa}$ & $3.19 \mathrm{Aa}$ \\
\hline AWG & $22.08 \mathrm{Ba}$ & $20.45 \mathrm{Ba}$ & $19.72 \mathrm{Ba}$ & $18.48 \mathrm{Ba}$ & $2.36 \mathrm{Ba}$ & $1.97 \mathrm{Ba}$ \\
\hline P25 & $22.58 \mathrm{Ba}$ & $21.60 \mathrm{Ba}$ & $20.86 \mathrm{Ba}$ & $19.99 \mathrm{Ba}$ & $1.72 \mathrm{Ba}$ & $1.61 \mathrm{Ba}$ \\
\hline P35 & $22.28 \mathrm{Ba}$ & $21.88 \mathrm{Ba}$ & $20.42 \mathrm{Ba}$ & $19.99 \mathrm{Ba}$ & $1.87 \mathrm{Ba}$ & $1.89 \mathrm{Ba}$ \\
\hline \multirow[t]{4}{*}{ P45 } & $20.90 \mathrm{Ba}$ & $21.15 \mathrm{Ba}$ & $19.15 \mathrm{Ba}$ & $19.51 \mathrm{Ba}$ & $1.75 \mathrm{Ba}$ & $1.64 \mathrm{Ba}$ \\
\hline & \multicolumn{2}{|c|}{ CV (1): 12.27} & \multicolumn{2}{|c|}{ CV(1): 11.72} & \multicolumn{2}{|c|}{ CV(1): 28.43} \\
\hline & \multicolumn{2}{|c|}{ CV (2): 9.71} & \multicolumn{2}{|c|}{ CV(2): 9.36} & & 4.43 \\
\hline & & & 0.20 & $10 \mathrm{~m}$ & & \\
\hline NCA & $26.28 \mathrm{Aa}$ & $25.52 \mathrm{Aa}$ & $23.27 \mathrm{Aa}$ & $22.79 \mathrm{Aa}$ & $3.01 \mathrm{Aa}$ & $2.72 \mathrm{Aa}$ \\
\hline AWG & $19.10 \mathrm{Ba}$ & $19.35 \mathrm{Ba}$ & $17.46 \mathrm{Ba}$ & $16.57 \mathrm{Ba}$ & $1.64 \mathrm{Aa}$ & $2.78 \mathrm{Aa}$ \\
\hline P25 & $18.50 \mathrm{Ba}$ & $18.97 \mathrm{Ba}$ & $16.88 \mathrm{Ba}$ & $17.64 \mathrm{Ba}$ & $1.62 \mathrm{Aa}$ & $1.33 \mathrm{Aa}$ \\
\hline P35 & $18.40 \mathrm{Ba}$ & 17.47 Ba & $16.22 \mathrm{Ba}$ & 16.11 Ba & $2.18 \mathrm{Aa}$ & $1.36 \mathrm{Aa}$ \\
\hline P45 & $17.77 \mathrm{Ba}$ & $16.57 \mathrm{Ba}$ & $15.36 \mathrm{Ba}$ & $15.21 \mathrm{Ba}$ & $2.41 \mathrm{Aa}$ & $1.36 \mathrm{Aa}$ \\
\hline & $\mathrm{CV}$ & 11.66 & $\mathrm{CV}$ & 4.61 & & 1.16 \\
\hline & $\mathrm{CV}$ & 3.18 & $\mathrm{CV}$ & 5.95 & & 7.89 \\
\hline
\end{tabular}

*Values followed by the same uppercase letters in the columns and lowercase letters in the rows does not significantly differ by the Tukey's test at 5\%. **Different pasture heights (P25 $0.25 \mathrm{~m}$; P35 $0.35 \mathrm{~m}$, and P45 $0.45 \mathrm{~m}$ ), areas without grazing (AWG) and a native vegetation area of the Cerrado biome $(\mathrm{NCA}) . \mathrm{PP}=$ post-pasture evaluation and $\mathrm{PC}=$ post-crop evaluation. $\mathrm{CV}(1)=$ coefficient of variation between treatments (\%), CV (2) = coefficient of variation between evaluation times (\%). 
The treatments presented similar TC contents in both evaluation times, except in the layer 0.0-0.05 m of the AWG, in which the TC content reduced from PP to PC (Table 2), with lower contents compared with the NCA in the layers $0.0-0.05 \mathrm{~m}(\mathrm{PC})$ and 0.05-0.10 $\mathrm{m}$ (PP and PC) (Table 2). Thus, the grazing affects the organic matter dynamic, accelerating nutrient cycling and recycling (ANGHINONI et al., 2013). The animal add manure to the soil, which is rapidly mineralized, since it has $\mathrm{C}: \mathrm{N}$ ratio of approximately 20:1 (WHITEHEAD, 2000).
Moreover, grazing increases the soil carbon content through the renewal of the pasture root system (MARTINS, 2013). Thus, the roots frequently and directly increase the soil carbon contents, which is less susceptible to loss compared with the carbon in the soil surface (RASSE et al., 2005). Therefore, the AWG lack of grazing and short time of implementation contributed to the reduction of the soil TC content, which is also observed by its reductions in F1 and F3 fractions compared with the NCA (Table 3).

Table 3. Very easily oxidizable (F1), easily oxidizable (F2), moderately oxidizable (F3) and resistant (F4) fractions, and recovery rate of the oxidizable fractions (RR) in an area with native vegetation (Cerrado biome) and areas with crop-livestock integration with different grazing intensities in no-tillage system.

\begin{tabular}{|c|c|c|c|c|c|c|c|c|c|c|}
\hline \multirow[b]{2}{*}{ Areas $^{* *}$} & \multicolumn{2}{|c|}{ F1 } & \multicolumn{2}{|c|}{ F2 } & \multicolumn{2}{|c|}{ F3 } & \multicolumn{2}{|c|}{ F4 } & \multicolumn{2}{|c|}{ RR (\%) } \\
\hline & PP & PC & PP & PC & $\mathbf{P P}$ & PC & PP & PC & PP & PC \\
\hline & \multicolumn{10}{|c|}{$0.0-0.05 \mathrm{~m}$} \\
\hline NCA & $8.1 \mathrm{Ab}^{*}$ & $13.8 \mathrm{Aa}$ & 7.4Aa & $9.0 \mathrm{Aa}$ & $10.2 \mathrm{Aa}$ & 7.7Aa & $10.6 \mathrm{Aa}$ & $8.4 \mathrm{Aa}$ & 98 & 89 \\
\hline AWG & $9.1 \mathrm{Aa}$ & $9.3 \mathrm{Ba}$ & 4.8Aa & $5.0 \mathrm{Aa}$ & $3.0 \mathrm{Ba}$ & $3.1 \mathrm{Ba}$ & $4.9 \mathrm{Ba}$ & $5.9 \mathrm{ABa}$ & 90 & 95 \\
\hline P25 & 7.6Aa & $8.4 \mathrm{Ba}$ & $5.6 \mathrm{Aa}$ & $5.2 \mathrm{Aa}$ & $5.3 \mathrm{Ba}$ & $5.5 \mathrm{ABa}$ & $2.8 \mathrm{Ba}$ & $4.8 \mathrm{Ba}$ & 92 & 94 \\
\hline P35 & 7.9Aa & $8.4 \mathrm{Ba}$ & $5.4 \mathrm{Aa}$ & $5.6 \mathrm{Aa}$ & $4.6 \mathrm{Ba}$ & $3.8 \mathrm{Ba}$ & $5.2 \mathrm{Ba}$ & $5.1 \mathrm{Ba}$ & 94 & 92 \\
\hline \multirow[t]{4}{*}{ P45 } & $7.7 \mathrm{Ab}$ & $9.0 \mathrm{Ba}$ & 4.9Aa & 5.7Aa & $4.8 \mathrm{Ba}$ & $3.9 \mathrm{Ba}$ & 4.2Ba & $4.7 \mathrm{Ba}$ & 93 & 97 \\
\hline & \multicolumn{2}{|c|}{ CV(1): 23.7} & \multicolumn{2}{|c|}{ CV(1): 47.9} & \multicolumn{2}{|c|}{ CV(1): 21.1} & \multicolumn{2}{|c|}{ CV(1): 24.4} & & \\
\hline & \multicolumn{2}{|c|}{ CV(2): 16.1} & \multicolumn{2}{|c|}{ CV(2): 33.9} & \multicolumn{2}{|c|}{$C V(2): 33.5$} & \multicolumn{2}{|c|}{ CV(2): 37.8} & & \\
\hline & \multicolumn{10}{|c|}{$0.05-0.10 \mathrm{~m}$} \\
\hline NCA & $8.6 \mathrm{Aa}$ & $9.4 \mathrm{Aa}$ & $6.0 \mathrm{Aa}$ & $6.6 \mathrm{Aa}$ & $6.8 \mathrm{Aa}$ & $6.4 \mathrm{Aa}$ & 7.6Aa & $7.8 \mathrm{Aa}$ & 94 & 82 \\
\hline AWG & $6.4 \mathrm{Ba}$ & $7.5 \mathrm{Ba}$ & $5.0 \mathrm{Aa}$ & $3.9 \mathrm{Aa}$ & $4.4 \mathrm{Ba}$ & $3.8 \mathrm{Ba}$ & $5.7 \mathrm{ABa}$ & $5.2 \mathrm{ABa}$ & 95 & 94 \\
\hline P25 & $6.1 \mathrm{Bb}$ & $8.6 \mathrm{ABa}$ & $5.4 \mathrm{Aa}$ & $3.4 \mathrm{Ab}$ & $6.5 \mathrm{ABa}$ & $5.8 \mathrm{ABa}$ & $3.7 \mathrm{Ba}$ & $4.0 \mathrm{Ba}$ & 94 & 93 \\
\hline P35 & $5.4 \mathrm{Bb}$ & 8.7ABa & $5.7 \mathrm{Aa}$ & $3.5 \mathrm{Ab}$ & 4.8ABa & $5.0 \mathrm{ABa}$ & $4.2 \mathrm{Ba}$ & $4.6 \mathrm{Ba}$ & 88 & 94 \\
\hline \multirow[t]{2}{*}{ P45 } & $6.9 \mathrm{ABb}$ & 8.7ABa & $5.1 \mathrm{Aa}$ & $3.5 \mathrm{Ab}$ & $4.0 \mathrm{Ba}$ & $4.3 \mathrm{ABa}$ & $4.0 \mathrm{Ba}$ & $4.0 \mathrm{Ba}$ & 88 & 93 \\
\hline & \multicolumn{2}{|c|}{ CV(1): 10.0} & \multicolumn{2}{|c|}{ CV(1): 31.0} & \multicolumn{2}{|c|}{ CV(1): 23.6} & \multicolumn{2}{|c|}{ CV(1): 30.6} & & \\
\hline
\end{tabular}

*Values followed by the same uppercase letters in the columns and lowercase letters in the rows does not significantly differ by the Tukey's test at 5\%. **Different pasture heights (P25 $0.25 \mathrm{~m}$; P35 $0.35 \mathrm{~m}$, and P45 $0.45 \mathrm{~m}$ ), areas without grazing (AWG) and a native vegetation area of the Cerrado biome (NCA). $\mathrm{PP}=$ post-pasture evaluation and $\mathrm{PC}=$ post-crop evaluation. $\mathrm{CV}(1)=$ coefficient of variation between treatments $(\%), \mathrm{CV}(2)=$ coefficient of variation between evaluation times $(\%)$.

The similar TC contents in the NCA and areas with different pasture heights in layers 0.00-0.05 $\mathrm{m}$ (PC) and 0.05-0.10 $\mathrm{m}$ (PP and PC) (Table 2) show that the pasture intensities used repaired the soil degradation caused by the previous pastures, despite the CLI short time of implementation. This result was due to changes in the SOM dynamic promoted by the increase in the amount and quality of organic residues added to the system by the grass and cattle (WHITEHEAD, 2000; MARTINS, 2013). According to Loss et al. (2012), CLI systems tend to increase the TC content in the soil, and, sometimes, even equalize and exceed the values found in native Cerrado vegetation areas due to the combination of several factors, such as their high plant production (dry mass) by the grass roots and shoots, plant residues from the annual crops, and fertilization. 
The treatments with different pasture heights showed no difference in soil TC content due to the CLI short time of implementation, however, the grazing affected positively, with the AWG area presenting lower SOM contents (Table 2). However, these results do not imply that AWG causes negative effects to the SOM dynamic at long term, since according to Pereira Neto et al. (2007) the period of implementation for the consolidation of a no-tillage system (NTS) and the soil chemical and structural attributes to reach similar values to those found in native forest, is at least nine years. The management systems were implemented in 2009 on a degraded area, thus, these areas were still on the recovery process, and the expectation is that carbon content increases. Therefore, further evaluations must be carried out in these areas to monitor the SOM dynamics.

The NCA had higher OCp contents compared with the other treatments in the layers 0.0-0.05 and $0.10-0.20 \mathrm{~m}$ (PP and PC) and 0.05-0.10 m (PP) (Table 2). This result can be attributed to the greater stability conditions of the SOM in the NCA, such as the continuous supply of plant residues of different $\mathrm{C}: \mathrm{N}$ ratios from litterfall and roots, the perennial vegetation and the absence of soil disturbances. According to Gazolla et al. (2015), the absence of disturbance and dense vegetation of the NCA have generated an environment that favors the input of $\mathrm{C}$ and residues to the soil, increasing the OCp contents, since this fraction is formed by particles from plant shoot and root residues.

The NCA showed higher OCm contents compared with the CLI areas and AWG in the soil layers 0.0-0.05 $\mathrm{m}$ (PC) and 0.10-0.40 $\mathrm{m}$ (PP and PC) (Table 2). The OCm of the soil layers 0.0-0.05 $\mathrm{m}$ (PP) and 0.05-0.10 m (PP and PC) of the areas was not statistically different, however, the values tended to be higher in the NCA compared with the other treatments (Table 2). These results are from CLI areas with short implementation time, compared with the many years of stability of the NCA. Thus, the CLI implementation time was still not sufficient to store $\mathrm{C}$ in this fraction, which may have been reduced throughout the pasture long time of degradation before the experiment implementation, since the OCm is a more recalcitrant and slowcycling fraction (BAYER et al., 2004), which makes it more stable and less sensitivity to changes caused by soil managements (SALTON, 2005).

The NCA had lower OCp contents in the rainy season(PC) in the 0.0 to $0.10 \mathrm{~m}$ (Table 2). Batista et al. (2013) also found sensitivity of OCp to seasonality. This result is due to the higher temperatures and humidity under NCA, which coincides with the PC, generating high rates of SOM due to a higher biomass production in this period and accelerating the SOM decomposition due to the greater activity of decomposing organisms from its fauna (BATISTA et al., 2013) and soil microorganisms (LEITE et al., 2010).

The NCA had greater contents of $\mathrm{C}$ of the fraction F1 in the layer 0.0-0.05 m (PC) compared with the other treatments, and higher contents of this fraction in the layer 0.05-0.10 m (PP) compared with the treatments AWG, P25 and P35 (Table 3). Similar results were found by Loss et al. (2012), with higher contents of fraction F1 in the Cerrado vegetation compared with CLI areas. These authors attributed this result to the greater input of plant residues and litterfall in the native Cerrado area. The F1 fraction is a more labile fraction, which is related to the inputs of fresh organic residues (litterfall and roots); and the NCA presents greater SOM stability, thus, the F1 fraction production is favored and maintained for a longer time in this environment.

The values of the fraction F1 (0.00-0.05 m, PP) and F2 (0.00-0.10 m, PP and PC) in the AWG, P25, $\mathrm{P} 35, \mathrm{P} 45$ were similar to those found in the NCA (Table 3). This similarity with NCA was also found in the layer $0.05-0.10 \mathrm{~m}$ (PP) for P45 and in the layer 0.05-0.10 m (PC) for P25, P35, P45 (Table 3). Loss et al. (2013) and Batista et al. (2014) also found similar contents of $\mathrm{C}$ of the fraction F1 and F2 in CLI and NCA. According to these authors, 
this result was due to the shoot and root residues of the Urochloa sp., which contributed to increase the TC in the off season, increasing the SOM labile fractions under conservation systems of soil use. The fractions F1 and F2 have greater lability, representing the forms of $\mathrm{C}$ recently added to the soil, similar to OCp; and the CLI areas add grass residues with high $\mathrm{C}: \mathrm{N}$ ratio into the soil surface layer, thus, the fractions $\mathrm{F} 1$ and $\mathrm{F} 2$ tend to be predominant in the PP period, remaining longer in the soil (PC) according to the chemical recalcitrance of their organic composition and amount of organic residues added to the soil.

The contents of fractions F1 $(0.05-0.10 \mathrm{~m}, \mathrm{PC})$ and F3 (0.0-0.05 m, PC; 0.05-0.10 m, PP and PC) were lower in the AWG compared with the NCA. These treatments had similar results for the fraction F4 in the layers $0.0-0.05 \mathrm{~m} \mathrm{(PC)} \mathrm{and} \mathrm{0.05-0.10}$ $\mathrm{m}$ (PP and $\mathrm{PC}$ ) (Table 3). These results help to explain the low TC values found in AWG (Table 2 ), since the introduction of grass in the rotation of the AWG was not sufficient to stabilize or increase the $\mathrm{C}$ contents lost throughout the many years of degradation before the experiment implementation. The reduction of fractions F1 and F3 and similar results for the fraction F4 compared with the NCA may have been caused by the lack of grazing, i.e., the absence of grazing caused the shoot residues to take longer to be degraded, due to their greater amount and higher $\mathrm{C}: \mathrm{N}$ ratio, moreover, the root system of this pasture had lower renewal rate, and absence of animal residue inputs, which have lower $\mathrm{C}: \mathrm{N}$ ratio and could contribute to accelerated the SOM mineralization. These factors make the plant residue mineralization slower, reducing the labile fraction and increasing the formation of recalcitrant organic compounds. According to Loss et al. (2013) the use of Brachiaria sp. in the NTS increases more recalcitrant oxidizable fractions, with high correlation with chemically stable humic substances, such as humin.

In general, the NCA had greater $\mathrm{C}$ content of the fraction F3 and F4 (0.0-0.05 m, PP) compared with the other treatments, as found for the fraction F3 in the treatments P35 and P45 (0.0-0.05 m, PC), P45 (0.05-0.10 m, PP) and for the fraction F4 in the treatments P25, P35 and P45 (0.0-0.05 m, PC; 0.05-0.10 m PP and PC) (Table 3). The fractions F3 and $\mathrm{F} 4$ present long term responses to management, with significant increases from at least 10 to 15 years (GUARESCHI et al., 2013). Thus, the impacts caused by the long period of practices that favored the degradation throughout at least 20 years before the implementation of the experiment (2009) are still present. These impacts are expressed by the greater contents of fractions F3 and F4 and $\mathrm{OCm}$ of the Cerrado area compared with the managed areas, regardless of the times and depths evaluated. The fractions F3 and F4 are related to the OCm due to their similar characteristics, such as recalcitrance and bond with mineral particles (silt and clay), forming organo-mineral complexes. Thus, greater contents of recalcitrant fractions (F3 and F4) in a non-disturbed area confirm the long term accumulation of organic compounds of higher chemical stability and molecular weight from the SOM decomposition and humification (RANGEL et al., 2008). Similarly, Loss et al. (2013) also found greater contents of $\mathrm{C}$ of fractions $\mathrm{F} 3$ and $\mathrm{F} 4$ in a Cerrado vegetation compared with a CLI area.

The contents of $\mathrm{C}$ of fraction F3 in the NCA were similar to those in the treatments P25 (0.0-0.05 m, PC); P25 and P35 (0.05-0.10 m, PP); and P25, P35 and P45 (0.05-0.10 m, PC) (Table 3). These results show that the grazing, especially of high (P25) and moderate (P35) intensity, and the organic residues from crops (soybean and pasture) and cattle manure, are contributing to form more recalcitrant organic substances. The fractions F3 and F4 are related to compounds of greater chemical stability and molecular weight, from the SOM decomposition and humification (STEVENSON, 1994). Batista et al. (2014) also found similar C contents of fraction F3 in NCA and CLI areas.

The NCA had the best balance of distribution of fractions $\mathrm{F} 1+\mathrm{F} 2$ and $\mathrm{F} 3+\mathrm{F} 4$ related to the $\mathrm{TC}$ in the 
soil layers and evaluation times (Table 4). The goal, in any system, is to achieve a fair balance, in which the labile fractions (F1 and F2), which are more easily decomposable organic matter, contributes with availability of nutrients and formation of macroaggregates (BLAIR et al., 1995; CHAN et al., 2001; LOSS, 2011), and the more resistant part of the soil (F3 and F4) contributes with improvement and maintenance of the soil physical properties and slower release of nutrients (CHAN et al., 2001; LOSS et al., 2010; GUARESCHI et al., 2013). The better balance of oxidizable fractions of SOM in NCA, compared with the other treatments, was due to several factors, such as their longer time in the soil, absence of human disturbances and constant supply of organic residues of different qualities (GUARESCHI et al., 2013).

Table 4. Carbon content (\%) of fractions F1+F2 and F3+F4 in the soil compared with the soil total carbon content (TC).

\begin{tabular}{|c|c|c|c|c|}
\hline \multirow{3}{*}{ Areas } & \multicolumn{3}{|c|}{ PP } & $\mathrm{PC}$ \\
\hline & \multicolumn{4}{|c|}{----------- 0.0-0.05 m ----------- } \\
\hline & $\mathrm{F} 1+\mathrm{F} 2(\%)$ & $\mathrm{F} 3+\mathrm{F} 4(\%)$ & $\mathrm{F} 1+\mathrm{F} 2(\%)$ & $\mathrm{F} 3+\mathrm{F} 4(\%)$ \\
\hline $\mathrm{NCA}$ & 42.8 & 57.2 & 58.5 & 41.5 \\
\hline AWG & 63.5 & 36.5 & 61.2 & 38.8 \\
\hline P25 & 62.1 & 37.9 & 56.8 & 43.2 \\
\hline P35 & 57.8 & 42.2 & 61.0 & 39.0 \\
\hline P45 & 58.4 & 41.6 & 63.0 & 37.0 \\
\hline \multirow{3}{*}{ Áreas } & \multicolumn{2}{|c|}{$\mathrm{PP}$} & \multicolumn{2}{|c|}{$\mathrm{PC}$} \\
\hline & \multicolumn{4}{|c|}{------------- 0.05-0.10 m ------------- } \\
\hline & $\mathrm{F} 1+\mathrm{F} 2(\%)$ & $\mathrm{F} 3+\mathrm{F} 4(\%)$ & $\mathrm{F} 1+\mathrm{F} 2(\%)$ & $\mathrm{F} 3+\mathrm{F} 4(\%)$ \\
\hline $\mathrm{NCA}$ & 50.2 & 49.8 & 53.1 & 46.9 \\
\hline AWG & 53.1 & 46.9 & 55.8 & 44.2 \\
\hline P25 & 52.7 & 47.3 & 54.9 & 45.1 \\
\hline P35 & 55.4 & 44.6 & 55.9 & 44.1 \\
\hline P45 & 60.2 & 39.8 & 59.5 & 40.5 \\
\hline
\end{tabular}

Considering the AWG and the areas managed with different pasture heights in the $\mathrm{PC}$ and all layers evaluated, the higher the grazing intensity (P25) the greater the distribution balance of the SOM oxidizable fractions (Table 4). The AWG, P35 and P45 had greater prevalence of labile fractions $(\mathrm{F} 1+\mathrm{F} 2)$. Thus, the high grazing intensity (P25) accelerated the SOM mineralization and stabilization processes, i.e., the partial removal of shoots by the cattle and the manure deposition, provided better conditions for SOM mineralization (reduction of $\mathrm{C}: \mathrm{N}$ ratio) and accelerated the pasture root renewal, thus contributing with carbon input to the soil surface and subsurface layers. Moreover, the high grazing intensity (P25) had greater nutrient contents (especially $\mathrm{N}$ ) in the soil from the cattle manure. Moderate and high grazing intensities has greater potential to accumulate carbon in the soil, due to the greater content of plant residues and manure in the soil surface and the higher root renewal rate, which is stimulated by grazing, causing greater root development and C accumulation (FUJISAKA et al., 1998) depending on the crop rotation used in the area (NICOLOSO et al., 2008; DIEKOW et al., 2005). 


\section{Conclusions}

The area without grazing had lower contents of total soil carbon and fractions F1 and F3, suggesting that the crop-livestock integration increases the organic matter content in the soil surface layer, regardless of the pasture height.

The contents of OCp and OCm of the areas without grazing and with different pasture heights in CLI was similar due to the experiment short time of implementation.

The fractionation of the oxidizable SOM was more sensitive in differentiating the treatments, showing that the greater grazing intensity (P25) provided a better balance of carbon accumulation between the SOM labile and recalcitrant fractions.

\section{References}

ANGHINONI, I.; CARVALHO, P. C. F.; COSTA, S. E. V. G. A. Tópicos em ciência do solo. In: ARAÚJO, A. P.; AVELAR, B. J. R. (Ed.). Abordagem sistêmica do solo em sistemas integrados de produção agrícola e pecuária no subtrópico brasileiro. 8. ed. Viçosa, MG: UFV, 2013. p. 221-278.

BATISTA, I.; CORREIA, M. E. F.; PEREIRA, M. G.; BIELUCZYK, W.; SCHIAVO, J. A.; MELLO, N. A. de; ROWS, J. R. C. Teores e estoque de carbono em frações lábeis e recalcitrantes da matéria orgânica do solo sob integração lavoura-pecuária no bioma Cerrado. Semina: Ciências Agrárias, Londrina, v. 34, n. 6, p. 3377-3388, 2013.

BATISTA, I.; CORREIA, M. E. F.; PEREIRA, M. G.; BIELUCZYK, W.; SCHIAVO, J. A.; ROUWS, J. R. C. Frações oxidáveis do carbono orgânico total e macrofauna edáfica em sistema de integração lavourapecuária. Revista Brasileira de Ciência do Solo, Viçosa, MG, v. 38, n. 3, p. 797-809, 2014.

BAYER, C.; MARTINNETO, L.; MIELNICZUK, J.; PAVINATO, A. Armazenamento de carbono em frações lábeis da matéria orgânica de um latossolo vermelho sob plantio direto. Pesquisa Agropecuária Brasileira, Brasília, v. 39, n. 7, p. 677-683, 2004.

BIELUCZYK, W. Atributos edáficos e agronômicos em sistema de integração lavoura-pecuária sob intensidades de pastejo em plantio direto no cerrado goiano. 2014. Dissertação (Mestrado em Agronomia - Ciência do
Solo) - Universidade Federal Rural do Rio de Janeiro, Seropédica, RJ.

BLAIR, G. J.; LEFROY, R. D. B.; LISLE, L. Soil carbon fractions based on their degree of oxidation, and the development of a carbon management index for agricultural systems. Australian Journal of Agricultural Research, Victoria, v. 46, n. 1, p. 1459-1466, 1995.

BONETTI, J. A.; PAUlinO, H. B.; SOUZA, E. D.; CARNEIRO, M. A. C.; SILVA, G. N. Influência do sistema integrado de produção agropecuária no solo e na produtividade de soja e braquiária. Pesquisa Agropecuária Tropical, Goiânia, v. 45, n. 1, p. 104-112, 2015.

CAMBARDELlA, C. A.; ELLIOTT, E. T. Particulate soil organic-matter changes across a grassland cultivation sequence. Soil Science Society of America Journal, Madison, v. 56, n. 1, p. 777-783, 1992.

CARMO, F. F.; FIGUEIREDO, C. C.; RAMOS, M. L. G.; VIVALDI, L. J.; ARAÚJO, L. G. Frações granulométricas da matéria orgânica em Latossolo sob plantio direto com gramíneas. Bioscience Journal, Uberlândia, v. 28, n. 3, p. 420-431, 2012.

CHAN, K. Y.; BOWMAN, A.; OATES, A. Oxidizidable organic carbon fractions and soil quality changes in an oxic paleustalf under different pasture ley. Soil Science, Baltimore, v. 166, n. 1, p. 61-67, 2001.

CIOTTA, M. N.; BAYER, C.; FONTOURA, S. M. V.; ERNANI, P. R; ALBUQUERQUE, J. A. Matéria orgânica do solo e aumento da capacidade de troca de cátions em solo com argila de atividade baixa sob sistema plantio direto. Ciência Rural, Santa Maria, v. 33, n. 6, p. 1161-1164, 2003.

DIEKOW, J.; MIELNICZUK, J.; KNICKER, H.; BAYER, C.; DICK, D. P.; KOGELKNABNER, I. Soil $\mathrm{C}$ and $\mathrm{N}$ stocks as affected by cropping systems and nitrogen fertilisation in a southern Brazil Acrisol managed under no-tillage for 17 years. Soil \& Tillage Research, Amsterdam, v. 81, n. 1, p. 87-95, 2005.

DONAGEMA, G. K.; CAMPOS, D. V. B. de; CALDERANO, S. B.; TEIXEIRA, W. G.; VIANA, J. H. M. (Org.). Manual de métodos de análise de solos. 2. ed. Rio de Janeiro: Embrapa Solos, 2011. 230 p.

EMPRESA BRASILEIRA DE PESQUISA AGROPECUÁRIA - EMBRAPA. Sistema brasileiro de classificação de solos. 3. ed. Rio de Janeiro: Embrapa Solos, 2013. 353 p.

FIGUEIREDO, C. C. de; RESCK, D. V. S.; CARNEIRO, M. A. C. Labile and stable fractions of soil organic matter under management systems and native cerrado. Revista 
Brasileira de Ciência do Solo, Viçosa, MG, v. 34, n. 3, p. 907-916, 2010.

FUJISAKA, S.; CASTILLA, C.; ESCOBAR, G.; RODRIGUES, V.; VENEKLAAS, E. J.; THOMAS, R.; FISHER, M. The effects of forest conversion on annual crops and pasture: estimates of carbon emissions and plant species loss in Brazilian Amazon colony. Agriculture, Ecossystems and Environment, Amsterdam, v. 69, n. 1, p. 17-26, 1998.

GAZOLLA, P. R; GUARESCHI, R. F.; PERIN, A.; PEREIRA, M. G.; ROSSI, C. Q. Frações da matéria orgânica do solo sob pastagem, sistema plantio direto e integração lavoura-pecuária. Semina: Ciências Agrárias, Londrina, v. 36, n. 2, p. 693-704, 2015.

GUARESCHI, R. F.; PEREIRA, M. G.; PERIN, A. Oxidizable carbon fractions in Red Latosol under different management systems. Revista Ciência Agronômica, Fortaleza, v. 44, n. 2, p. 242-250, 2013.

LEITE, L. F. C.; FREITAS, R. C. A.; SAGRILO, E.; GALVÃO, S. R. S. Decomposição e liberação de nutrientes de resíduos vegetais depositados sobre Latossolo Amarelo no Cerrado Maranhense. Revista Ciência Agronômica, Fortaleza, v. 41, n. 1, p. 29-35, jan./ mar. 2010.

LOSS, A. Dinâmica da matéria orgânica, fertilidade e agregação do solo em áreas sob diferentes sistemas de uso no cerrado goiano. 2011. Tese (Doutorado em Agronomia - Ciência do Solo) - Universidade Federal Rural do Rio de Janeiro, Seropédica.

LOSS, A.; MORAES, A. G. L.; PEREIRA, M. G.; SILVA, E. M. R.; ANJOS, L. H. C. Carbono, matéria orgânica leve e frações oxidáveis do carbono orgânico sob diferentes sistemas de produção orgânica. Comunicata Scientiae, Bom Jesus, PI, v. 1, n. 1, p. 57-64, 2010.

LOSS, A.; PEREIRA, M. G.; FERREIRA, E. P.; SANTOS, L. L.; BEUTLER, S. J.; FERRAZ JÚNIOR, A. S. L. Frações oxidáveis do carbono orgânico em argissolo vermelho-amarelo sob sistema de aléias. Revista Brasileira de Ciência do Solo, Viçosa, MG, v. 33, n. 1, p. 867-874, 2009.

LOSS, A.; PEREIRA, M. G.; PERIN, A.; COUTINHO, F. S.; ANJOS, L. H. C. Particulate organic matter in soil under different management systems in the Brazilian Cerrado. Soil Research, Clayton, v. 50, n. 8, p. 685-693, 2012.

LOSS, A.; PEREIRA, M. G.; PERIN, A.; BEUTLER, S. J.; ANJOS, L. D. Oxidizable carbon and humic substances in rotation systems with brachiaria/livestock and pearl millet/no livestock in the Brazilian Cerrado.
Spanish Journal of Agricultural Research, Madrid, v. 11, n. 1, p. 217-231, 2013.

MAIA, S. M. F.; XAVIER, F. A. S.; OLIVEIRA, T. S.; MENDONÇA, E. S.; ARAÚJO FILHO, J. A. Organic carbon pools in a Luvisol under agroforestry and conventional farming systems in the semi-arid region of Ceará, Brazil. Agroforestry Systems, Dordrecht, v. 71, n. 2, p. 127-138, 2007.

MARTHA JUNIOR, G. B.; ALVES, E. R. de A.; CONTINI, E. Dimensão econômica de sistemas de integração lavoura-pecuária. Pesquisa agropecuária Brasileira, Brasília, v. 46, n. 10, p. 1117-1126, 2011.

MARTINS, A. P. Acidez do solo e reaplicação de calcário em sistema de integração lavoura-pecuária em plantio direto. 2013. Dissertação (Mestrado em Ciência do Solo) - Universidade Federal do Rio Grande do Sul, Santa Maria.

NICOLOSO, R. S.; LOVATO, T.; AMADO, T. J. C.; BAYER, C.; LANZANOVA, M. E. Balanço do carbono orgânico no solo sob integração lavoura-pecuária no sul do Brasil. Revista Brasileira de Ciência do Solo, Viçosa, MG, v. 32, n. 6, p. 2425-2433, 2008.

OORTS, K.; VANLAUWE, B.; MERCKX, R. Cation exchange capacities of soil organic matter fractions in a Ferri Lixisol with different organic matter inputs. Agriculture, Ecossystems and Environment, Amsterdam, v. 100, n. 1, p. 161-171, 2003.

PEREIRA NETO, O. C.; GUIMARÃES, M. D. F.; RALISCH, R.; FONSECA, I. C. Análise do tempo de consolidação do sistema de plantio direto. Revista Brasileira de Engenharia Agrícola e Ambiental, Campina Grande, v. 11, n. 5, p. 489-496, 2007.

RANGEL, O. J. P.; SILVA, C. A.; GUIMARAES, P. T. G.; GUILHERME, L. R. Frações oxidáveis do carbono orgânico de Latossolo cultivado com cafeeiro em diferentes espaçamentos de plantio. Ciência $e$ Agrotecnologia, Lavras, v. 32, n. 2, p. 429-437, 2008.

RASSE, D. P.; RUMPEL, C.; DIGNAC, M. F. Is soil carbon mostly root carbon? Mechanisms for a specific stabilisation. Plant and Soil, The Hague, v. 269, n. 1-2, p. 341-356, 2005.

RESCK, D. V. S.; FERRREIRA, E. A. B.; FIGUEIREDO, C. C.; ZINN, Y. L. Dinâmica da matéria orgânica no cerrado. In: SANTOS, G. A.; SILVA, L. S.; CANELLAS, L. P.; CAMARGO, F. A. O. Fundamentos da matéria orgânica do solo: ecossistemas tropicais e subtropicais. 2. ed. Porto Alegre: Editora Cinco Continentes, 2008. p. 359-417. 
ROSSI, C. Q.; PEREIRA, M. G.; GIÁCOMO, S. G.; BETTA, M.; POLIDORO, J. C. Frações lábeis da matéria orgânica em sistema de cultivo com palha de braquiária e sorgo. Revista Ciência Agronômica, Fortaleza, v. 43, n. 1, p. 38-46, 2012.

SALTON, J. C. Matéria orgânica e agregação do solo na rotação lavoura-pastagem em ambiente tropical. 2005. Tese (Doutorado em Ciência do Solo) - Universidade Federal do Rio Grande do Sul, Porto Alegre.

SALTON, J. C.; MIELNICZUK, J.; BAYER, C.; FABRÍCIO, A. C.; MACEDO, M. C. M.; BROCH, D. L. Teor e dinâmica do carbono no solo em sistemas de integração lavoura-pecuária. Pesquisa Agropecuária Brasileira, Brasília, v. 46, n. 10, p. 1349-1356, 2011.

SOUSA, D. M. G.; LOBATO, E. Cerrado: correção do solo e adubação. 2. ed. Brasilia: Embrapa, 2004. 416 p.
STEVENSON, F. J. Humus chemistry: Genesis, composition, reactions. $2^{\text {th }}$ ed. New York: John Wiley e Sons, 1994. 496 p.

TIRLONI, C.; VITORINO, A. C. T.; BERGAMIN, A. C.; SOUZA, L. C. F. Physical properties and particlesize fractions of soil organic matter in crop-livestock integration. Revista Brasileira de Ciência do Solo, Viçosa, MG, v. 36, n. 4, p. 1299-1309, 2012.

WHITEHEAD, D. C. Nutrient elements in grassland soil-plantanimal relationships. Wallingford: $\mathrm{CAB}$ International, 2000. $369 \mathrm{p}$.

YEOMANS, J. C.; BREMNER, J. M. A rapid and precise method for routine determination of organic carbon in soil. Communications in Soil Science and Plant Analysis, New York, v. 19, n. 1, p. 1467-1476, 1988. 
